\title{
Ceramic-like Composite Systems for Winding Insulation of Electrical Machines
}

\author{
Sören Miersch, Ralph Schubert, Thomas Schuhmann, Uwe Schuffenhauer, Markus Buddenbohm, \\ Markus Beyreuther, Jeannette Kuhn, Mathias Lindner, Bernd Cebulski and Jakob Jung
}

\begin{abstract}
Insulating sheets, impregnants and encapsulation materials commonly used for winding insulation offer low thermal conductivities. This leads to an increased heating of the winding of electrical machines and to the existence of hotspots. The electromagnetical utilization of the machine has to be reduced with respect to the allowed maximum winding temperature. In this paper, the development and experimental investigation of novel polysiloxane composites with ceramic fillers are presented. The materials are tested by means of impregnated and encapsulated samples of a round-wire winding as well as the main insulation of electrical steel sheets and laminated cores. Numerical models are implemented for determining the equivalent thermal conductivity of the winding compound comprising the enameled wire and the impregnant. Based on the example of a permanent-magnet synchronous machine with outer-rotor in modular construction, the potential for increasing the electromagnetical utilization is shown.
\end{abstract}

Index Terms -- Electric machines, insulation technology, ceramics, thermal variables measurement, cooling, thermal analysis, numerical simulation, traction motors, modular machines, outer rotor.

\section{INTRODUCTION}

$\mathrm{T}$ HE winding insulation of electric machines consists of main insulation to the laminated core, the phase insulation inside the slot (two-layer winding) and the conductor insulation. In the low-voltage range, for insulating sheets mainly polyester foils with a thickness of $(0.15 \ldots 0.3) \mathrm{mm}$ and a specific thermal conductivity $<0.2 \mathrm{~W} /(\mathrm{m} \cdot \mathrm{K})$ are used. The enameled insulation of the copper wires consists e.g. of polyurethane and also shows a thermal conductivity of approx. $0.2 \mathrm{~W} /(\mathrm{m} \cdot \mathrm{K})$. For improving the dissipation of copper losses, the winding is impregnated, sometimes winding heads are encapsulated. To avoid air inclusions, the usage of vacuum (pressure) impregnation (VPI) is recommended. For unfilled impregnants based on epoxide or polyurethane, the thermal conductivities are approx. $0.2 \mathrm{~W} /(\mathrm{m} \cdot \mathrm{K})$. From [1]-[4] it is known that for filled impregnants specific thermal conductivities in the range $(1 \ldots 3) \mathrm{W} /(\mathrm{m} \cdot \mathrm{K})$ are reachable. With increasing filling degree, the processing properties deteriorate. The small thermal conductivities of the insulating materials are causing strong heating of the stator winding. In case of wide slots as well as in the end-winding region thermal hotspots occur. The electromagnetical utilization has to be limited with respect to the maximum allowable winding temperature (e.g.

This work is part of a project in the Industrial Collective Research (IGF) from Consortium of Industrial Research Associations (AiF) and is supported by the German Federal Ministry of Economic Affairs and Energy (BMWi).

S. Miersch, Th. Schuhmann, U. Schuffenhauer and M. Buddenbohm are with the University of Applied Sciences Dresden, Faculty Electrical Engineering, Dresden, Germany (e-mail: soeren.miersch@htw-dresden.de)

R. Schubert, M. Beyreuther and J. Kuhn are with the Fraunhofer Institute for Ceramic Technologies and Systems IKTS, Polymerceramic Composites, Hermsdorf, Germany (e-mail: ralph.schubert@ikts.fraunhofer.de)

M. Lindner, B. Cebulski and J. Jung are with IAV GmbH, Stollberg, Germany (e-mail: mathias.lindner@iav.de) thermal class $\mathrm{H}$ : $\left.\theta_{\mathrm{w} \cdot \max } \leq 180^{\circ} \mathrm{C}\right)$. In [5] it is shown that by means of coating of copper wires with ceramic materials (e.g. aluminum oxide $\mathrm{Al}_{2} \mathrm{O}_{3}$ ) the thermal conductivity of the winding compound can be increased by factor 2.5. For highvoltage machines, in [6] and [7] the utilization of ceramic fillers up to filling grades of 25 vol.- $\%$ are investigated. In doing so, the thermal conductivity of the impregnant is doubled and the winding over temperature decreases about approx. $10 \mathrm{~K}$. Manufacturing and processing of highly filled ceramic systems as in [8] have to be rated as critical. Moreover, by implementing polymer-ceramic composite materials the operating temperature can be increased up to $>300{ }^{\circ} \mathrm{C}$, which has been proven by development of ceramically encapsulated sensors and starting resistors [9]. Besides the development of novel insulation materials, a necessary research task is the design of adequate simulation models for the winding compound. Approaches are the layer model presented in [10] and [11] or the determination of an equivalent thermal conductivity based on numerical simulation results as shown in [12] and [5].

In this paper the development of ceramic-like polysiloxane composites for impregnation and encapsulation of windings of electrical machines as well as for injection molding and brush or dip coating of the main insulation towards the laminated core are presented. As fillers, $\mathrm{Al}_{2} \mathrm{O}_{3}$, AlN und $\mathrm{BN}$ are investigated. Numerical models are used for deriving equivalent thermal conductivities of the winding compound and for demonstration of possible improvements. The project aims at increasing the electromagnetical utilization of electrical machines in the power range $>10 \mathrm{~kW}$, as they are used e.g. for (hybrid) electric vehicles.

\section{DEVELOPMENT AND CHARACTERIZATION OF MATERIALS}

The aim is to develop novel ceramic-like insulation materials based on filled polysiloxanes. For the material used for winding impregnation and winding encapsulation a thermal conductivity $>1 \mathrm{~W} /(\mathrm{m} \cdot \mathrm{K})$, for the injection molding material used for main insulation $>2 \mathrm{~W} /(\mathrm{m} \cdot \mathrm{K})$ is aspired at a temperature stability of $\theta_{\max }>250{ }^{\circ} \mathrm{C}$. The material composition and processing conceptions are derived from the development of inorganic-organic composite materials for housing of sensors and electrical devices under severe thermal load [13]. These materials are characterized by the ability of plastic forming (e.g. pouring, injection molding) based on the use of liquid or thermo-plastic silicone resins as well as ceramic like properties, in particular an improved thermal conductivity in the result of partial transformation of the organic composite matrix into inorganic components after heat treatment.

\section{A. Development of composite impregnation and coating materials}

The polymer matrix of the composite material consists of a mixture of liquid methyl-phenyl-polysiloxanes, in which the 
viscosity can be adjusted by additives of the same chemical constitution as the base polymer. The polymer matrix crosslinks by a polyaddition mechanism without byproducts, thus allowing the formation of a dense and pore free body. The polymer matrix was filled with ceramic powders in order to increase the thermo-mechanical stability and thermal conductivity. Aluminum oxide $\left(\alpha-\mathrm{Al}_{2} \mathrm{O}_{3}\right)$, aluminum nitride (AIN), and hexagonal boron nitride $(\alpha-\mathrm{BN})$ were chosen as fillers. The aluminum containing minerals are applied in form of fine-grained powders with an average particle size in the range of $(2 \ldots 6) \mu \mathrm{m}$, whereas the boron nitride filler represents a pre-granulated powder with an average particle size of $30 \mu \mathrm{m}$. The solids have been pretreated by coating with siloxanes as described in [14] before integration into the polymer matrix with the aim of higher filling degrees without deterioration of flowability and a reasonable processing stability. Filling degrees of the aluminum oxide and nitride up to 50 vol.- $\%$ and 30 vol.- $\%$ of the boron nitride could be achieved.

The composite impregnation and coating materials were manufactured by a simple stirring process at $80^{\circ} \mathrm{C}$. The liquid mixtures did not show any separation tendency over several days. The composites can be cross-linked after impregnation or coating and vacuum degassing at temperatures in the range of $(160 \ldots 200){ }^{\circ} \mathrm{C}$ under normal pressure in the range of (4...8) hours.

\section{B. Development of injection-moldable composites for slot insulation}

The polymer matrix of injection-moldable composites for slot insulation consists of a thermo-plastic base silicone resin and liquid additives of the same chemical composition. With the help of the additives the flowability of the molten material can be adjusted. The silicone resins are cross-linked by a polycondensation mechanism at $180{ }^{\circ} \mathrm{C}$ with water as byproduct. Due to the formation of water the cross-linking has to be carried out under pressure (e.g. by injection molding) to avoid the formation of pores.

The polymer system has been filled with the same ceramic fillers as the impregnation materials. Additionally, short glass fibers (cut length $3 \mathrm{~mm}$ ) and needle shaped minerals like wollastonite $\left(\mathrm{CaSiO}_{3}\right.$, average length $\left.(10 \ldots 15) \mu \mathrm{m}\right)$ were used for mechanical reinforcement. Overall filling degrees of (50...60) vol.-\% could be achieved by optimization of the silicone additives.

The composite materials were prepared by a shear roll compaction technique at $80{ }^{\circ} \mathrm{C}$. For the slot insulation, they will be processed by thermo-set injection molding (melting temperature $80^{\circ} \mathrm{C}$, injection pressure 400 bar, cross-linking temperature $180^{\circ} \mathrm{C}$, cross-linking time $60 \mathrm{~s}$ ).

Measured characteristics of technological, mechanical, thermal, and electrical properties of the composite materials for slot insulation are summarized in TABLE I.

\section{Summary of material parameters}

Important properties like composition, processing parameters (viscosity, cross-linking temperature and time) and mechanical, thermal and electrical characteristics have been determined by means of measurements. The results are summarized in TABLE I below. The method and the results of characterization of thermal conductivity of the composite materials and test specimen as a central focus of the research and development activities are described more in detail below.

TABLE I

MEASURED COMPOSITE MATERIAL PROPERTIES FOR IMPREGNATION AND SLOT INSULATION

\begin{tabular}{|c|c|c|c|}
\hline Property & Method & $\begin{array}{l}\text { Impreg- } \\
\text { nation / } \\
\text { Coating }\end{array}$ & $\begin{array}{l}\text { Injection } \\
\text { molding }\end{array}$ \\
\hline filling degree & & $40 /$ & 50 \\
\hline $\begin{array}{l}\text { (vol.- } \%) \\
\text { viscosity }(\mathrm{Pa} \cdot \mathrm{s})\end{array}$ & & $\begin{array}{c}30(\mathrm{BN}) \\
1.3-5\end{array}$ & 10000 \\
\hline $\begin{array}{l}\text { cross-linking time } \\
\text { (min) }\end{array}$ & & $240-480$ & $1-2$ \\
\hline $\begin{array}{c}\text { flexural strength } \\
(\mathrm{MPa})\end{array}$ & ISO 178 & $20-35$ & $50-65$ \\
\hline $\begin{array}{c}\text { coefficient of } \\
\text { thermal expansion } \\
(\mathrm{ppm} / \mathrm{K})\end{array}$ & ISO $11359-2$ & $100-120$ & $35-50$ \\
\hline $\begin{array}{l}\text { thermal } \\
\text { conductivity }\end{array}$ & ISO $22007-2$ & $\begin{array}{c}0.83 \\
\left(\mathrm{Al}_{2} \mathrm{O}_{3}\right)\end{array}$ & $\begin{array}{c}1.0 \\
\left(\mathrm{Al}_{2} \mathrm{O}_{3}\right)\end{array}$ \\
\hline$(\mathrm{W} /(\mathrm{m} \cdot \mathrm{K}))$ & & $1.16(\mathrm{AlN})$ & $2.2(\mathrm{AlN})$ \\
\hline specific electrical & DIN EN & $\begin{array}{c}2.76(\mathrm{BN}) \\
10^{15}\end{array}$ & $\begin{array}{c}4(\mathrm{BN}) \\
10^{14}\end{array}$ \\
\hline resistance $(\Omega \cdot \mathrm{cm})$ & $62631-3 / 1-2$ & & \\
\hline $\begin{array}{l}\text { break through } \\
\text { voltage }(\mathrm{kV} / \mathrm{cm})\end{array}$ & $\begin{array}{l}\text { DIN EN } \\
60243-1\end{array}$ & $20-25$ & 23 \\
\hline
\end{tabular}
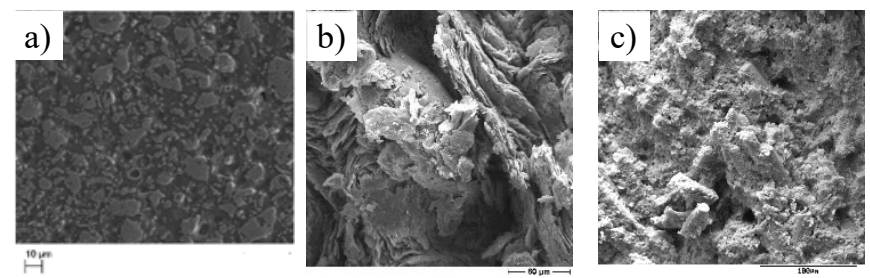

Fig. 1. Microstructure of the composite materials a) AlN filled impregnation material (scale $10 \mu \mathrm{m}$ )

b) $\mathrm{BN}$ filled impregnation material (scale $60 \mu \mathrm{m}$ )

c) $\mathrm{Al}_{2} \mathrm{O}_{3}$ filled and glass fiber reinforced slot insulation (scale $100 \mu \mathrm{m}$ )

Investigation of microstructure of the composites for impregnation and slot insulation with a field emission raster electron microscope Ultra 55 plus (Zeiss) revealed a smooth integration of the filler components into the polymer matrix. The boron nitride filler behaves differently. Here, the big grain size, the platelet structure, and the special surface interfere a wetting with the matrix polymer and a more even powder distribution in the composite matrix (cf. Fig. 1).

\section{EXPERIMENTAL INVESTIGATION OF TEST SAMPLES}

The objective of the experimental investigation of test samples is to prove to what extend the specific thermal conductivity can be increased in comparison to common insulating materials. Moreover, the investigations help evaluating the impregnation results and the bonding of the injection molded and brush or dip coated main insulation to the laminated core.

\section{A. Manufacturing of test samples}

Next to filled material samples based on the characteristics mentioned above, different compound samples made from enameled copper wire (grade 2) coated with polyurethane and the characterized impregnation materials have been produced (cf. Fig. 2). Impregnation is carried out at laboratory conditions under vacuum and at a casting temperature of $140{ }^{\circ} \mathrm{C}$. 
The bare round wire has a diameter of $0.85 \mathrm{~mm}$ and the mean thickness of the wire insulation is $35.5 \mu \mathrm{m}$. The flat wire $(2.8 \times 1.25) \mathrm{mm}^{2}$ has an insulation thickness of $50 \mu \mathrm{m}$. For the round wire samples a copper filling degree $\varphi_{\mathrm{Cu}}$ of $57 \%$ was achieved by loose wire stacking in an impregnation mold. The flat wire sample manufactured the same way as the round wire sample offers a filling degree of $78 \%$.

The round wire samples could be impregnated with the highly filled impregnation composite materials completely and showed a stable mechanical bonding after mechanical processing, whereas the flat wire samples were impregnated incompletely and decomposed partially after mechanical processing due to the much smaller amount of joining impregnation material between the wires. (cf. Fig. 2).

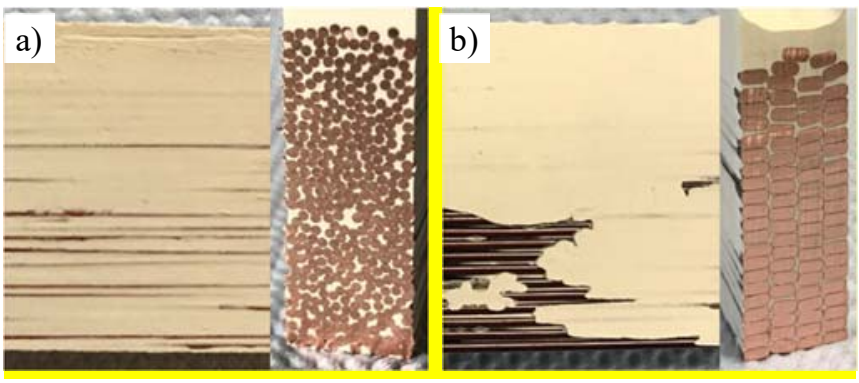

Fig. 2. Impregnated test samples

(a) round wire coil segment, b) flat wire coil segment)

To analyze the thermal conductivity of the compound of main insulation and laminated cores, test samples made from steel laminations M400-50A have been encapsulated by injection molding (cf. Fig. 3 a) and brush coating (cf. Fig. 3 b). The injection molded layers with various thicknesses in the range of $(0.5 \ldots 2.0) \mathrm{mm}$ adhere poorly to the laminated steel cores and cracked at its edges. This is caused by the special constitution of the polysiloxane matrix of the injection molding system comprising anti-adhesive additives and forming more rigid polymer structures in the result of cross-linking. In contrast the brush coated layers with thicknesses in the range of $(0.05 \ldots 0.3) \mathrm{mm}$ showed good adhesion and no crack formation even after heat treatment at $200{ }^{\circ} \mathrm{C}$ for 1 hour (cf. Fig. 3 c).
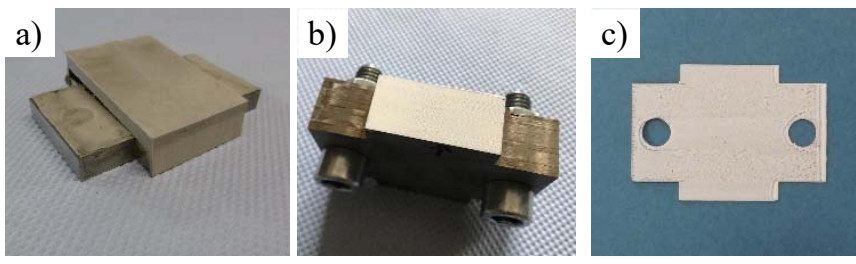

Fig. 3. Main insulation of laminated core made by:

(a) injection molding, b) brush coating, and c) brush coating with subsequent heat treatment $200{ }^{\circ} \mathrm{C}, 1$ hour)

\section{B. Characterization of thermal conductivity}

Thermal conductivity was measured with the transient plane source technique (hot disk method) as described in [15]. The Hot Disk TPS 2500S device (C3 Prozess- und Analysentechnik $\mathrm{GmbH}$ ) was used to define the thermal conductivity of the pure impregnation and encapsulating composites as well as of test samples of impregnated copper coils. The investigations of the pure composite samples show that the thermally highly conductive ceramic fillers and the comparatively high filling degrees cause improved thermal conductivities $(0.8$ to $4 \mathrm{~W} /(\mathrm{m} \cdot \mathrm{K}))$ compared to standard polymer materials $(0.2 \mathrm{~W} /(\mathrm{m} \cdot \mathrm{K}))$. The coil segment samples exhibit even higher thermal conductivities due to the high amount of encapsulated copper wires $(6.26 \mathrm{~W} / \mathrm{m} \cdot \mathrm{K}$ with $\mathrm{Al}_{2} \mathrm{O}_{3}$ filled impregnation, $7.23 \mathrm{~W} / \mathrm{m} \cdot \mathrm{K}$ with $\mathrm{AlN}$ filled impregnation compared to $2.15 \mathrm{~W} / \mathrm{m} \cdot \mathrm{K}$ with standard polyester impregnation).

\section{Investigation of microstructure}

Micrographs of the interface between the copper wires and impregnation material show a complete filling and even distribution of the polysiloxane composite without any disturbances like cracks or pores (cf. Fig. 4 a). The impregnation material wets the wires completely and the thermal conductive fillers are distributed homogeneously and dense even between narrow interspaces between the wires (cf. Fig. 4 b).

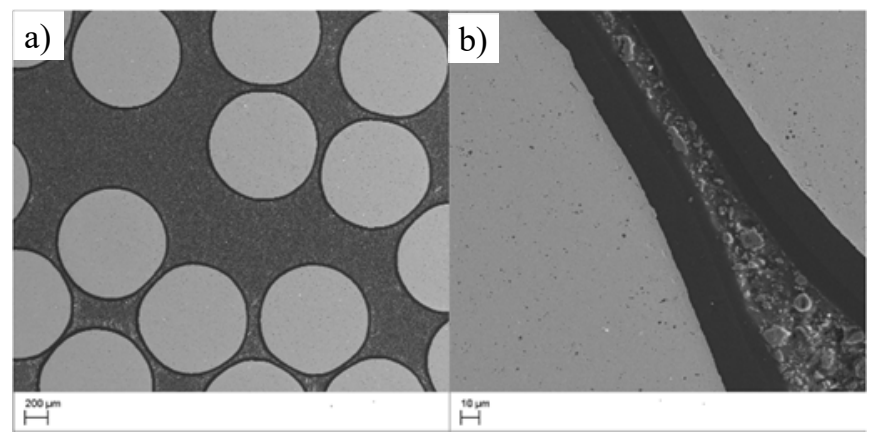

Fig. 4. Microstructure of the interface between the AlN filled composite and the encapsulated wires in an impregnated coil segment (scale $200 \mu \mathrm{m} / 10 \mu \mathrm{m}$ )

\section{Planning of further investigations}

Regarding the perpetuating development tasks the buildup of wound stators and their impregnation under practical conditions are planned. By means of destructive tests and partial discharge measurements the impregnation result shall be evaluated. Based on experiments, the comparison to conventional insulated test stators at defined cooling conditions and impressed losses is projected to show the potential of the novel insulating materials. Additionally, the temperature cycle stability shall be proven. For finishing the project, the buildup and experimental investigation of the test machine presented in CHAPTER V. is planned. The goal is an increase of the electromagnetic utilization about $>10 \%$. By means of the experimental results, the numerical models shall be validated.

\section{NUMERICAL DETERMINATION OF EQUIVALENT THERMAL CONDUCTIVITY}

For analyzing the thermal behavior of electric machines by means of numerical models, modeling of the winding by means of an orthotropic equivalent thermal conductivity is recommendable. Subsequently, a numerical model for determination of this equivalent thermal conductivity is presented.

Analogous to the experimental investigation of the roundwire samples, the calculation of the equivalent thermal conductivity of the winding compound inside the slot is performed by means of the ANSYS ${ }^{\circledR}$ CFX numerical simulation model presented in Fig. 5. A symmetrical section of the assumed orthocyclic configuration has been chosen. For the whole winding compound inside the slot analyzed at a later time (cf. 
model in Fig. 9) the boundary effects at the round wire winding and the slot-side insulation are modeled by means of a contact resistance. The variation of the copper fill factor is realized by means of the model dimensions at constant parameters of the enameled copper wire, the thermal conductivity of the impregnant is varied. At the boundaries of the model a constant temperature difference $\Delta \theta=80 \mathrm{~K}$ is specified and the heat flow $\Phi_{\text {th }}$ is determined by integrating the heat flow density over the model side surface $A$. The thermal resistance $R_{\text {th }}$ of the system results from the ratio of temperature difference and heat flow, the equivalent thermal conductivity in tangential direction $\lambda_{\text {equ.wt }}$ is defined by

$$
\lambda_{\text {equ.wt }}=\frac{l}{R_{\mathrm{th}} \cdot A} .
$$

In the ongoing research activities, it is projected to derive approximated analytical relations for calculating the equivalent thermal conductivity from the numerical results which shall be compared to literature.

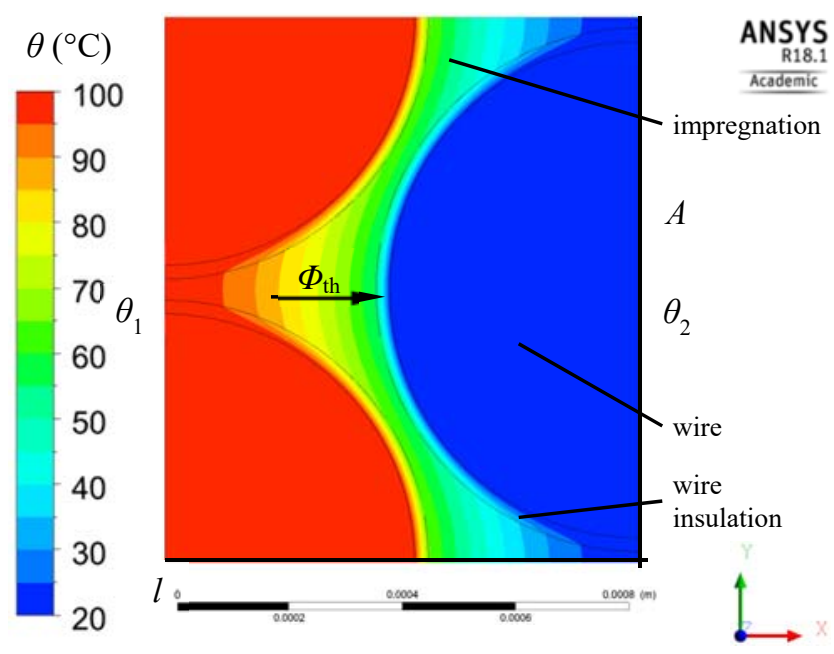

Fig. 5. Calculation of equivalent thermal conductivity

(using measured material characteristics from CHAPTER II. Wire: $d_{\mathrm{Cu}}=0.884 \mathrm{~mm}, \quad b_{\text {iso }}=24.6 \mu \mathrm{m}, \quad \lambda_{\mathrm{Cu}}=385 \mathrm{~W} /(\mathrm{m} \cdot \mathrm{K}) \quad \lambda_{\text {iso }}=0.2 \mathrm{~W} /(\mathrm{m} \cdot \mathrm{K})$; impregnation: standard $\lambda_{\text {imp }}=0.196 \mathrm{~W} /(\mathrm{m} \cdot \mathrm{K})$ and ceramics composite $\lambda_{\mathrm{Al} 2 \mathrm{O} 3}=0.833 \mathrm{~W} /(\mathrm{m} \cdot \mathrm{K})$ and $\left.\lambda_{\mathrm{AlN}}=1.165 \mathrm{~W} /(\mathrm{m} \cdot \mathrm{K})\right)$

By enlarging the specific thermal conductivity the equivalent thermal conductivity of the winding compound can be increased significantly (Fig. 6: copper fill factor: $\varphi_{\mathrm{Cu}}=50 \%$ and impregnation thermal conductivity $\lambda_{\text {imp }}: 0.196 \mathrm{~W} /(\mathrm{m} \cdot \mathrm{K})$ $\rightarrow 1.165 \mathrm{~W} /(\mathrm{m} \cdot \mathrm{K}) \rightarrow$ winding compound equivalent thermal conductivity $\left.\lambda_{\text {equ.wt_ } 1.165 \mathrm{~W} /(\mathrm{m} \cdot \mathrm{K})}=3.58 \cdot \lambda_{\text {equ.wt_ } 0.196 \mathrm{~W} /(\mathrm{m} \cdot \mathrm{K})}\right)$. With increasing slot fill factor $\varphi_{\mathrm{Cu}}$ the share of ceramic-like impregnant is reduced with regard to the share of the wire insulation, which specific thermal conductivity is constant at $0.2 \mathrm{~W} /(\mathrm{m} \cdot \mathrm{K})$. Thus, the relative increase of the compounds equivalent thermal conductivity is reduced. In further research activities, ceramic-like materials for wire insulation shall be developed. Those materials shall have an increased thermal conductivity, good slip properties as well as high thermal and mechanical stability.

For the following thermal calculation of the modular traction machine, Fig. 6 is used to determine the equivalent thermal conductivity. To verify the simulation results, simula- ted values were compared with measured values of the composite. It was found that with the hot disk method used, a lot of heat is dissipated in axial sample direction via the copper wire. Therefore, the method is only suitable for measuring thermal conductivity of homogenous samples, such as the ceramic-filled impregnation. Measured values of the composite samples were about three and a half times higher than the simulation values, which has to be considered as unrealistic. With regard to further work, a measurement in analogy to the test setup in [5] is planned.

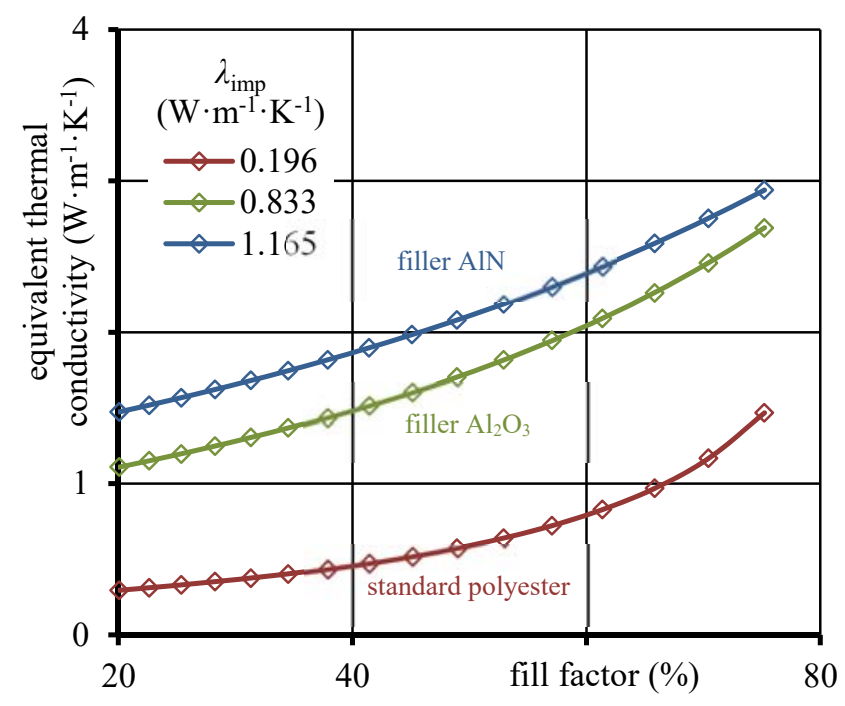

Fig. 6. Equivalent thermal conductivity of the winding compound in dependency from copper fill factor (simulation using measured material characteristics from CHAPTER II. )

\section{DESIGN OF PROTOTYPE MACHINE AND DEMONSTRATION OF POTENTIAL FOR IMPROVEMENT}

By means of the prototype machine, the potential for improvement by using ceramic-like insulating materials shall be shown. A modular machine concept has been chosen.

\section{A. Modular machine for electric traction drives}

As demonstrator, a ten-pole, permanent magnet excited synchronous machine with surface-mounted magnets was chosen. Due to the high electromagnetic utilization of the machine intended for use in electric mobility, water cooling is required. It has 15 stator slots filled with a three-phase, twolayer concentrated tooth coil winding (main dimensions cf. TABLE II). Aiming at the optimization of the manufacturing

TABLE II

MAIN DIMENSIONS OF MODULAR TRACTION MACHINE

\begin{tabular}{|c|c|c|c|}
\hline Parameter & $\begin{array}{l}\text { Dimen- } \\
\text { sion }\end{array}$ & Parameter & $\begin{array}{l}\text { Dimen- } \\
\text { sion }\end{array}$ \\
\hline $\begin{array}{c}\text { stator outer } \\
\text { diameter }(\mathrm{mm})\end{array}$ & 104.4 & $\begin{array}{c}\text { stator inner } \\
\text { diameter }(\mathrm{mm})\end{array}$ & 39.5 \\
\hline $\begin{array}{c}\text { rotor outer } \\
\text { diameter }(\mathrm{mm})\end{array}$ & 130.4 & $\begin{array}{c}\text { rotor inner } \\
\text { diameter }(\mathrm{mm})\end{array}$ & 114.4 \\
\hline $\begin{array}{l}\text { air gap length } \\
(\mathrm{mm})\end{array}$ & 1 & $\begin{array}{l}\text { active length } \\
(\mathrm{mm})\end{array}$ & 43 \\
\hline $\begin{array}{l}\text { magnet thickness } \\
(\mathrm{mm})\end{array}$ & 4 & $\begin{array}{l}\text { magnet length } \\
(\mathrm{mm})\end{array}$ & 15 \\
\hline $\begin{array}{c}\text { magnet } \\
\text { remanence flux } \\
\text { density }(\mathrm{T})\end{array}$ & 1.22 & $\begin{array}{c}\text { magnet } \\
\text { coercivity } \\
(\mathrm{kA} / \mathrm{m})\end{array}$ & 914 \\
\hline
\end{tabular}




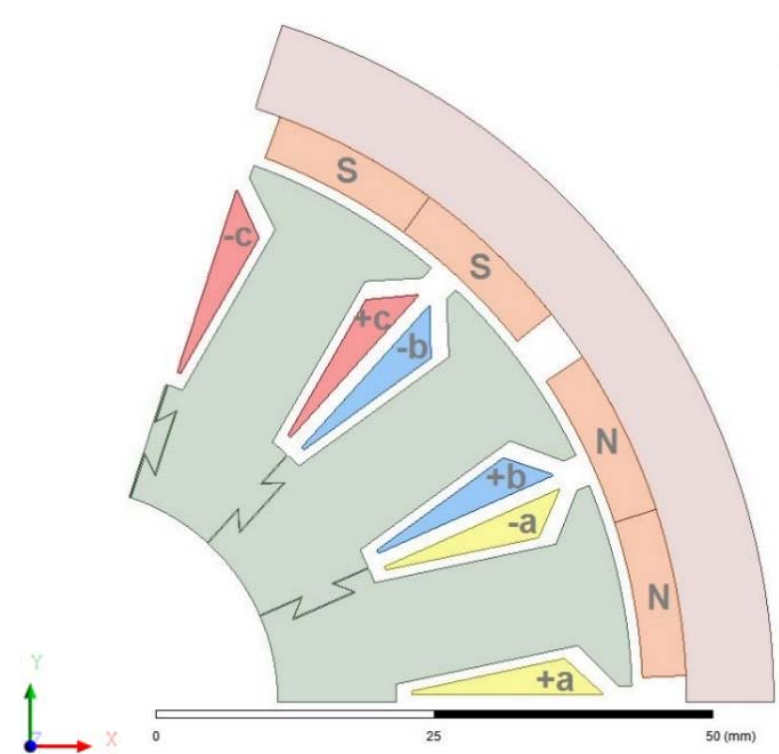

Fig. 7. Modularization concept of prototype machine

processes the stator is made from single T-segments (cf. Fig. 7). This allows encapsulating the tooth with the main insulation with a simpler coating process and a tooth coil winding with high copper fill factor. The material properties of the NdFeB magnets given in TABLE II are related to an assumed average magnet temperature of $120^{\circ} \mathrm{C}$. In the practically realized test machine, the magnets will be segmented axially to reduce the eddy current losses inside the magnets. During the electromagnetically field simulations it became clear that by keeping reasonable manufacturing tolerances the joining gap in the stator back iron does not lead to a remarkable increase of the cogging torque.

\section{B. Loss model}

By means of a transient electromagnetical FEA Simulation in ANSYS ${ }^{\circledR}$ Maxwell the remagnetization losses inside the stator lamination stack and the permanent magnets are calculated. The losses in the electrical steel sheets have to be analyzed separately in the stator teeth and stator back iron respectively due to the different magnetic loading. The specific core losses are evaluated in the simulation model by means of the JORDAN approach

$$
p_{\mathrm{Fe}}=K_{\mathrm{h}} \cdot B_{\max }^{2} \cdot f+K_{\mathrm{c}} \cdot\left(B_{\max } \cdot f\right)^{2}
$$

for the separate frequency components, whereat the coefficients of the specific hysteresis and eddy current losses $K_{\mathrm{h}}$ and $K_{\mathrm{c}}$ are determined based on the loss curves for different frequencies provided by the manufacturer (electric steel sheet of type M270-35A was chosen). For the modular machine, the remagnetization loss density as shown in Fig. 8 for one time step has been determined. Manufacturing-related additional factors taken from [16] are taken into account for calculating the remagnetization losses in TABLE III. In the region of the joining the losses are increased locally, for the version shown in Fig. 8 the remagnetization losses of the stator are increased about approx. $4 \%$ with regard to the unsegmented machine. The ohmic losses in the stator winding, the additional losses as well as the mechanical friction losses are calculated analytically based on [16] and [17], whereby the ohmic losses are calculated separately for the active machine length and the end-winding region. For the iterative calculation of the ohmic losses the average winding temperature taken from the numerical simulation (Fig. 10a) is used. In TABLE III the calculated losses for operating points at rated and maximum power are presented. At rated point a thermal loading $A \cdot J$ ( $A$ electric loading, $J$ current density) of $296\left(\mathrm{kA} / \mathrm{m} \cdot \mathrm{A} / \mathrm{mm}^{2}\right)$ is observed for the outer rotor machine, whereby a water cooling inside the stator tube is projected. Compared to inner rotor machines, which allow for thermal loadings up to $550\left(\mathrm{kA} / \mathrm{m} \cdot \mathrm{A} / \mathrm{mm}^{2}\right)$ for water cooling (cf. [18]) or other concepts of airstreamcooled wheel hub motors [19] the projected thermal loading of the prototype machine seems reachable due to the intense stator tube cooling, which shall be proven by the following simplified thermal calculation.

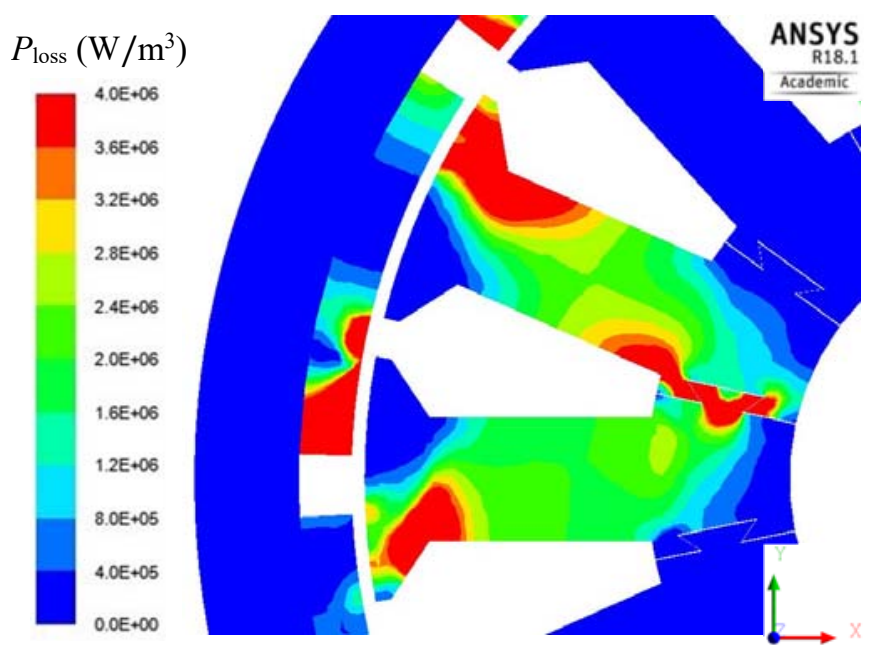

Fig. 8. Distribution of remagnetization loss density for one time step at rated point.

TABLE III

SEPARATION OF LOSS PARTS FOR SELECTED OPERATING POINTS

\begin{tabular}{c|c|c} 
Operating point & $\begin{array}{c}\text { Rated } \\
\text { power }\end{array}$ & $\begin{array}{c}\text { Max. } \\
\text { power }\end{array}$ \\
\hline \hline operation mode & $\mathrm{S} 1$ & $\mathrm{~S} 2-20 \mathrm{~s}$ \\
mechanical power $(\mathrm{kW})$ & 9.41 & 26.17 \\
average torque $(\mathrm{Nm})$ & 12.4 & 34.5 \\
speed $(\mathrm{rpm})$ & 7244 & 7244 \\
\hline \hline core loss stator tooth $(\mathrm{W})$ & 354.0 & 359.2 \\
core loss stator back iron $(\mathrm{W})$ & 82.0 & 87.0 \\
core loss rotor yoke $(\mathrm{W})$ & 0.38 & 2.24 \\
remag. loss magnets $(\mathrm{W})$ & 123 & 709 \\
ohmic loss slot $(\mathrm{W})$ & 107.5 & 982.2 \\
ohmic loss end winding $(\mathrm{W})$ & 51.8 & 472.8 \\
additional loss $(\mathrm{W})$ & 94.1 & 261.7 \\
mechanical loss $(\mathrm{W})$ & 8.2 & 8.2 \\
\hline \hline total loss $(\mathrm{kW})$ & 0.82 & 2.88 \\
efficiency $(\%)$ & 92.0 & 90.1 \\
utilization $\left(\mathrm{kVA} \cdot \mathrm{min} / \mathrm{m}^{3}\right)$ & 2.84 & 8.00 \\
thermal loading $\left(\mathrm{kA} / \mathrm{m} \cdot \mathrm{A} / \mathrm{mm}^{2}\right)$ & 296 & 2661 \\
\hline
\end{tabular}

\section{Simplified thermal simulation model}

The analysis of the thermal behavior of the modular machine is carried out by means of a numerical model in ANSYS $^{\circledR}$ CFX (cf. Fig. 9). For simplification a symmetrical section of the stator, comprising stator tooth and back iron, winding inside slot, winding head, slot wedge, stator tube and heat sink, is modeled. The heat sink and the stator tube made from aluminum offer a thermal conductivity of $209 \mathrm{~W} /(\mathrm{m} \cdot \mathrm{K})$. 
The orthotropic thermal conductivity of the lamination stack (M270-35A) is calculated iteratively based on the mean iron temperature under consideration of the lamination insulation. It amounts to $\lambda_{\mathrm{Fe} . \mathrm{t}}=24.5 \mathrm{~W} /(\mathrm{m} \cdot \mathrm{K})$ in tangential (and radial) direction and $\lambda_{\mathrm{Fe} . \mathrm{n}}=0.9 \mathrm{~W} /(\mathrm{m} \cdot \mathrm{K})$ in normal direction referred to lamination plane. Based on the numerical model in Fig. 5 and the equivalent thermal conductivities in Fig. 6 for the round wire winding with $d_{\mathrm{Cu}}=0.71 \mathrm{~mm}, b_{\text {iso }}=52 \mu \mathrm{m}$ and $\varphi_{\mathrm{Cu}}=45 \%$ we obtain the equivalent thermal conductivities in tangential direction between $\lambda_{\text {equ.wt } \_.2 \mathrm{~W} /(\mathrm{m} \cdot \mathrm{K})}=0.52 \mathrm{~W} /(\mathrm{m} \cdot \mathrm{K})$ and $\lambda_{\text {equ.wt_ } 2 \mathrm{~W} /(\mathrm{m} \cdot \mathrm{K})}=1.34 \mathrm{~W} /(\mathrm{m} \cdot \mathrm{K})$. With the slot filling factor $\varphi_{\mathrm{Cu}}$ for the normal direction referred to coil cross section $\lambda_{\mathrm{wn}}=173.3 \mathrm{~W} /(\mathrm{m} \cdot \mathrm{K})$ is calculated. For the slot wedge made from insulation material a thermal conductivity of $0.11 \mathrm{~W} /(\mathrm{m} \cdot \mathrm{K})$ is assumed. In the model from Fig. 10a, a contact resistance for the slot side insulation (insulating paper, $0.25 \mathrm{~mm}$ and $0.11 \mathrm{~W} /(\mathrm{m} \cdot \mathrm{K}))$ is calculated. For the slot side insulation made by tooth encapsulation in model Fig. 10b (thickness $0.2 \mathrm{~mm}$ and $1.1 \mathrm{~W} /(\mathrm{m} \cdot \mathrm{K})$ ) are assumed. Moreover, in the contact resistance a skin layer of the winding with $0.5 \mathrm{~mm}$ thickness and the thermal conductivity of the impregnant $\lambda_{\text {imp }}$ is taken into account. Between the slot wedge and the tooth tip, a gap filled with impregnant (length $0.5 \mathrm{~mm}$ ) is modeled by means of a contact resistance. For the shrink fit between lamination stack and stator tube the parameters $0.2 \mathrm{~W} /(\mathrm{m} \cdot \mathrm{K})$ and $10 \mu \mathrm{m}$ are assumed, for the adhesive layer between stator tube and heat sink the parameters $3 \mathrm{~W} /(\mathrm{m} \cdot \mathrm{K})$ and $50 \mu \mathrm{m}$. For the simplified thermal model, it is assumed that the losses arising in the permanent magnetically excited rotor are dissipated via the bearing shield to the cooling system and ambient. In the rated operating point (cf. TABLE III) for the stator tooth a loss density of $2.36 \cdot 10^{6} \mathrm{~W} / \mathrm{m}^{3}$ and in the stator back iron a loss density of $1.11 \cdot 10^{6} \mathrm{~W} / \mathrm{m}^{3}$ are impressed. For single tooth windings the mean winding temperatures in the slot and end winding region are nearly the same $(\Delta T \leq 1.5 \mathrm{~K})$ because of the short heat conduction path in the end windings. For both regions an identical loss density is impressed. For both simulations in Fig. 10 the ohmic losses are calculated iteratively in dependency from the mean winding temperature. The loss densities in the winding account for Fig. 10a $1.45 \cdot 10^{6} \mathrm{~W} / \mathrm{m}^{3}$ and for Fig. $10 \mathrm{~b}$ $1.37 \cdot 10^{6} \mathrm{~W} / \mathrm{m}^{3}$. The reference temperature of the thermal simulation in Fig. 10 is $40^{\circ} \mathrm{C}$. Regarding the convective boundary conditions in the air gap a rotor surface temperature of $120^{\circ} \mathrm{C}$ is assumed. For the air gap heat transfer of the outer rotor machine a convective heat transfer coefficient $h_{\delta}=64.3 \mathrm{~W} /\left(\mathrm{m}^{2} \cdot \mathrm{K}\right)$ is calculated based on [20]. The heat transfer coefficient at the winding head of the stator has been analyzed by means of a separate, coupled thermal-fluiddynamical CFD-simulation. In ANSYS ${ }^{\circledR}$ CFX the air flow in the internal air area is simulated and a temperature difference between end winding and bearing shield is specified. The heat flow is determined by integrating the the numerically calculated heat flow density on the walls, the resulting thermal resistance leads to the heat transfer coefficient. In dependency from the average rotor circumferential speed $v_{\mathrm{r}}$ the relation

$$
\begin{gathered}
h_{\mathrm{w}}=(-0.0193 \\
\cdot\left(\frac{\mathrm{v}_{\mathrm{r}}}{\mathrm{m} / \mathrm{s}}\right)^{2}+2.792 \cdot\left(\frac{\mathrm{v}_{\mathrm{r}}}{\mathrm{m} / \mathrm{s}}\right) \\
+9.42) \cdot \frac{\mathrm{W}}{\mathrm{m}^{2} \cdot \mathrm{K}}
\end{gathered}
$$

was derived. For $v_{\mathrm{r}}=29.63 \mathrm{~m} / \mathrm{s}$ this yields a heat transfer coefficient of $h_{\mathrm{w}}=75.2 \mathrm{~W} /\left(\mathrm{m}^{2} \cdot \mathrm{K}\right)$. The inner air region of the prototype machine is assumed to have a temperature of $120{ }^{\circ} \mathrm{C}$. For the liquid cooling inside the stator tube, initially an equivalent heat transfer coefficient of $12000 \mathrm{~W} / \mathrm{m}^{2} \cdot \mathrm{K}$ is assumed. This takes into account the convective heat transfer as well as a possible increase of the convective surface by the factor 3. The warming of the coolant $\Delta \theta_{\mathrm{fl}}$ is calculated during the iterative thermal calculation by means of

$$
\Delta \theta_{\mathrm{fl}}=\frac{\Phi_{\mathrm{th} . \mathrm{fl}}}{Q_{\mathrm{fl}} \cdot \rho_{\mathrm{fl}} \cdot c_{\mathrm{p} . \mathrm{fl}}}
$$

from the impressed heat flow $\Phi_{\text {th.fl }}$, the volume flow $Q_{\mathrm{fl}}$, the density $\rho_{\mathrm{fl}}$ and the specific heat capacity $c_{\mathrm{p} . \mathrm{fl}}$ of the fluid. In case of the intensified inner stator tube cooling at $Q_{\mathrm{fl}}=4 \mathrm{l} / \mathrm{min}$ a coolant warming of only $2.6 \mathrm{~K}$ results, which is taken into account fifty/fifty over the specified temperature boundary conditions at the heat sink.

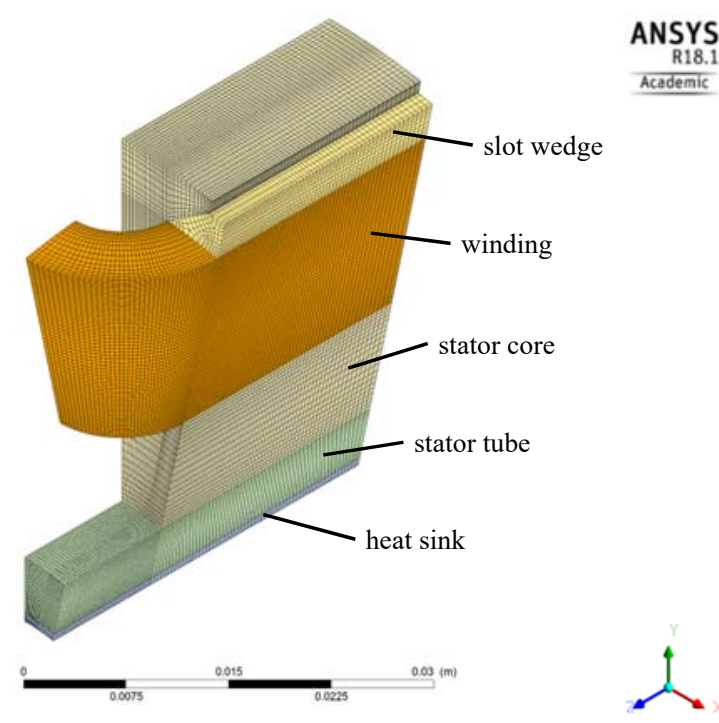

Fig. 9. Numerical model for calculation of thermal behavior

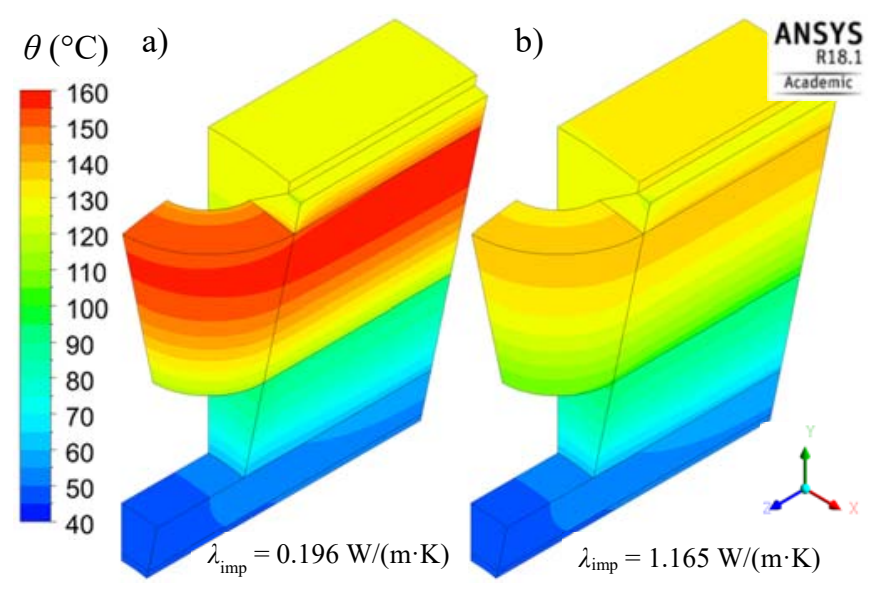

Fig. 10. Comparison of temperature distribution for different thermal conductivities of the impregnant

In Fig. 10 a comparison of the temperature distribution under variation of the thermal conductivity from the impregnant and the slot side insulation is carried out based on the assumptions above. In case of the conventional winding insulation in Fig. 10a, the maximum winding temperature 
amounts for $\theta_{\mathrm{w} \cdot \max }=159.2^{\circ} \mathrm{C}$ and the mean winding over temperature $\Delta \theta_{\mathrm{w}}=107 \mathrm{~K}$. With respect to the permissible mean winding over temperature for thermal class $\mathrm{H}(125 \mathrm{~K}) \mathrm{a}$ thermal reserve of $18 \mathrm{~K}$ can be stated. By increasing the specific thermal conductivity of the insulation (Fig. 10b) the maximum winding temperature can be decreased about 21.7 $\mathrm{K}$ and the mean winding temperature about $19.8 \mathrm{~K}$. With the simulation models described above it can be estimated that the electromagnetic utilization in the rated operating point can be increased by approx. $10 \%$ due to the novel, ceramic-like insulation materials.

With regard to ongoing work the numerical model has to be extended to the overall machine, whereby the design of the stator tube liquid cooling will be done by means of a coupled thermal-fluid-dynamical CFD-simulation.

\section{CONCLUSION}

In this paper, it has been shown that ceramic-like composite systems based on filled polysiloxanes are basically applicable for coating encapsulation of teeth, for establishing the slot main insulation as well as impregnation of the winding of electrical machines, whereas the composites optimized for injection molding are not suitable for realizing the slot main insulation. For the main insulation material, a specific thermal conductivity of approx. $1.1 \mathrm{~W} /(\mathrm{m} \cdot \mathrm{K})$ und for the impregnant of approx. $1.2 \mathrm{~W} /(\mathrm{m} \cdot \mathrm{K})$ were proven experimentally. In ongoing research work, the suitability for manufacturing and the capacity to withstand stresses of the insulating materials will be tested. The equivalent thermal conductivity of the winding compound can be increased approx. by the factor $2 \ldots 3$ compared to conventional insulating materials, whereby limitations result from the usage of conventional enameled copper wire. Thus, further research should focus on ceramic coatings of copper wires. On the example of a modular outer rotor machine for electric vehicle drives it has been shown that the mean winding temperature can be reduced about approx. $20 \mathrm{~K}$ by using ceramic-like insulating materials, related to a potential increase of the electromagnetic utilization of approx. $10 \%$.

\section{REFERENCES}

[1] Übler, W.: Erhöhung der thermischen Leitfähigkeit elektrisch isolierender Polymerwerkstoffe. Dissertation. Erlangen: Universität ErlangenNürnberg, Technische Fakultät, 2002

[2] Rost, S.: Vor- und Nachteile unterschiedlicher Verguss-Systeme (EP PU, SI). 3. Fachtagung E-Motoren und Transformatoren des Fachverbandes EWIS, Fulda, Germany: 01/2013

[3] Benedek, C.: Maßgeschneiderte PU-Vergussmassen und deren Zielkonflikte. 3. Fachtagung E-Motoren und Transformatoren des Fachverbandes EWIS, Fulda, Germany: 01/2013

[4] Hollstein, W.: Giessharzsysteme und Technologien für den Vollverguss des Stators bei Motoren und Generatoren. 3. Fachtagung E-Motoren und Transformatoren des Fachverbandes EWIS, Fulda, Germany: $01 / 2013$

[5] Simpson, N.; Mellor, P. H.; Wrobel, R.: Estimation of Equivalent Thermal Parameters of Electrical Windings. 20th International Conference on Electrical Machines, France, Marseille: 2012, p. 1294 1300

[6] Tomášková, T.; Trnka, P.: The influence of thermal properties of aluminum oxide on electrical insulating materials. 15th International Scientific Conference on Electric Power Engineering, Czech Republic, Brno: 2014, p. 421 - 425

[7] Tomášková, T.; Pechanek, R.; Kindl, V.: Benefits of Upgrading Insulating Materials to Operating Temperature of Induction Motor. 17th European Conference on Power Electronics and Applications, Switzerland Geneva: 2015, p. 1 - 6
[8] Yao, Y.; Gu, L.; Fan, T.; et al.: Evaluation of Heat Transfer Characteristic of Aluminum Nitride (AlN) Potting Compound for the End Windings of Permanent Magnet Synchronous Machines. 2nd International Conference on Electrical and Control Engineering, China, Yichang: 2011, p. 4498 - 4501

[9] Schubert, R.; Tupaika, F.; Kuhn, J.: Funktionell modifizierte anorganische-organische Composite-Werkstoffe. Kriegesmann, J; Deutsche Keramische Gesellschaft (DKG) (Hrsg.): Technische Keramische Werkstoffe. Wilster: HvB Verlag, 2012, 126. Erg.-Lfg.

[10] Staton, D. A.; Boglietti, A.; Cavagnino, A.: Solving the More Difficult Aspects of Electric Motor Thermal Analysis in Small and Medium Size Industrial Induction Motors. In: IEEE Transactions on Energy Conversion, 2005, Vol. 20, No. 3, p. 620 - 628

[11] Boglietti, A.; Cavagnino, A.; Staton, D. A.: Determination of Critical Parameters in Electrical Machine Thermal Models. In: IEEE Transactions on Industry Applications, 2008, Vol. 44, No. 4, p. 1150 - 1159

[12] Idoughi, L.; Mininger, X.; Bouillault, F.; et al.: Thermal Model With Winding Homogenization and FIT Discretization for Stator Slot. In: IEEE Transactions on Magnetics, 2011, Vol. 47, No 12, p. 4822 - 4826

[13] Schubert, R.; Tupaika, F.; Kuhn, J.: Polymerkeramische Komposite für den Einsatz unter hoher thermischer Belastung. In: Keramische Zeitschrift, 2007, Vol. 59, No. 2, p. 94 - 99

[14] Schubert, R.: Entwicklung funktionalisierter polymerkeramischer Komposite, Schlussbericht zum Teilprojekt 4.4, Innovativer regionaler Wachstumskern Partikeldesign Thüringen, Förderkennzeichen: 03WKCN04D, 2018

[15] Krupa, P; Malinaric, S.: Using the Transient Plane Source Method for Measuring Thermal Parameters of Electroceramic, In: International Journal of Mechanical and Mechatronics Engineering, 2014, Vol. 8, No. 5, 2014, p. 735 - 740

[16] Müller, G.; Vogt, K.; Ponick, B.: Berechnung elektrischer Maschinen. 6., völlig neu bearb. Aufl. Weinheim: WILEY-VCH Verlag, 2008

[17] Pyrhönen, J.; Jokinen, T.; Hrabovcová, V.: Design of Rotating Electrical Machines. Chichester: John Wiley \& Sons Ltd, 2008

[18] Deak, C.; Binder, A.: Design of Compact Permanent-Magnet Synchronous Motors with Concentrated Windings. In: Revue roumaine des sciences techniques. Série Électrotechnique et Énergétique, 2007, Vol. 52, No. 2, p. 183 - 197

[19] Reis, K.; Binder, A.: Development of a permanent magnet outer rotor direct drive for use in wheel-hub drives. 21st International Conference on Electrical Machines, Germany, Berlin: 2014, p. 2424 - 2430

[20] Miersch, S.; Eckart, M.; Schuffenhauer, U.; et al.: Coupled calculation of a permanent magnet-excited small wind energy generator in outer rotor construction cooled in the stator tube. 7. VDE/VDI - Fachtagung Antriebssysteme 2017, Germany, Karlsruhe: 2017, ETG-Fachbericht 154 , p. $69-76$

\section{BIOGRAPHIES}

Sören Miersch received the M.Sc. degree in electrical engineering from the University of Applied Sciences Dresden, Germany in 2008. Currently, he works as a research engineer in the field of electrical machines with the Department of Electrical Engineering at the University of Applied Sciences Dresden and he is a Ph.D. student at the Technical University Dresden. His fields of work include the thermal and electromagnetic design of electric machines.

Ralph Schubert received the Dipl.-Chem. degree in physical chemistry from the State University of St. Petersburg, Russia in 1988. From 1988 to 1992 he was employed as a scientific assistant at the Department of Solid State Chemistry of the Friedrich Schiller University, Jena. He moved to the Hermsdorfer Institute für Technische Keramik e.V. in Hermsdorf, Germany in 1993 which was integrated into the Fraunhofer Institute of Ceramic Technologies and Systems in 2009. In the competence center for composite materials there, he is mainly responsible for the development of inorganic-organic composite materials, their processing by plastic forming techniques, and also for the development of industrial applications based on the developed materials.

Thomas Schuhmann received the Dipl.-Ing. degree in electrical engineering from Chemnitz University of Technology, Germany in 2005 and the Dr.-Ing. degree in electrical engineering from Dresden University of Technology, Germany in 2011. Since 2010 he has been with Siemens AG, Business Unit Large Drives, Nuremberg, Germany in the development department for high power electrical machines. In 2013 he joined IAV GmbH, Chemnitz, Germany (E-traction department). Since 2016 he teaches as a professor at Dresden University of Applied Sciences. His main research interests are modeling, design and control of electrical machines. 